\title{
IMPACT OF NURSERY SEEDING DENSITY, NITROGEN, AND SEEDLING AGE ON YIELD AND YIELD ATTRIBUTES OF FINE RICE
}

\author{
Naeem Sarwa $^{1 *}$, Muhammad Maqsood ${ }^{1}$, Syed Aftab Wajid ${ }^{1}$, and Muhammad Anwar-ul-Haq ${ }^{1}$
}

Producing vigorous seedlings and transplanting them at the appropriate age are the most important factors for obtaining high yield in rice (Oryza sativa L.) paddy production. The impact of seeding densities, N, and seedling age was evaluated in this experiment after transplanting 10,20,30 and 40-d old seedlings raised by using different seeding rates (high and low) and $\mathrm{N}$ conditions (with and without) in the 2008 and 2009 rice growing seasons. The study revealed that 10 -d-old nursery seedlings, irrespective of seeding densities and fertilizer application, showed higher yields and yield attributes (productive tillers, plant height, 1000-grain weight, and straw yield), while at later stages significant interaction was observed with nursery management. Transplanting of 20-d older fertile seedlings grown with low seeding density at nursery-bed, resulted in a higher number of productive tillers $\mathrm{m}^{-2}(233.3,227.3)$, straw yield $\left(11.1,10.7 \mathrm{t} \mathrm{ha}^{-1}\right)$, and final yield $\left(3.6,3.4 \mathrm{t} \mathrm{ha} \mathrm{s}^{-1}\right)$ in both years, 2008 and 2009, respectively. Yield and yield attributes were significantly reduced by transplanting older seedlings grown at high seeding density and without $\mathrm{N}$ application at nursery-bed. Minimum productive tillers (165.7, 133), straw yield $\left(8.7,8.1 \mathrm{t} \mathrm{ha}^{-1}\right)$ and paddy yield $\left(2.0,1.8 \mathrm{t} \mathrm{ha}^{-1}\right)$ were recorded with transplanting 40-d older seedlings grown at high seeding density and without $\mathrm{N}$ application. These findings support the use of young seedling in a system of rice intensification and illustrate that by making a minor additional investment to raise healthy and vigorous seedlings in nursery seed-bed, farmers can improve yields.

Key words: Rice, nursery, seedling age, yield, Oryza sativa.

$\mathrm{R}$ ice (Oryza sativa L.) is the third largest crop after wheat (Triticum aestivum L.) and cotton (Gossypium hirsutum L.) and second major grain crop in Pakistan. It accounts for $5.9 \%$ of value added in agriculture and $1.3 \%$ of Pakistan's gross domestic product (Federal Bureau of Statistics, 2008; 2009). Rice production in Pakistan occupies an area of 2.96 million hectares, with a total production of 6.95 million tons and an average yield of $2.35 \mathrm{t} \mathrm{ha}^{-1}$ (Federal Bureau of Statistics, 2008; 2009).

Although rice in Pakistan is grown on large areas, its yield is far below the levels obtained in other rice producing countries, in spite of growing high yielding varieties. There are several reasons behind this but one of the most important is that nurseries are not properly managed to obtain vigorous seedlings for uniform stand and better seedling establishment. Padalia (1980) and Lal and Roy (1996) explained that the success of transplanted rice cultivation depends upon the seedling. Among the different components of nursery management, adequate nutrition, better seeding densities and transplanting seedlings at the appropriate age represent important factors to obtain vigorous stands after transplanting (Lal and Roy, 1996). Above- and below-ground characteristics of rice plants, before and after transplanting, vary with

${ }^{1}$ University of Agriculture, Department of Agronomy, Faisalabad 38040, Pakistan. "Corresponding author (bajwa834@gmail.com). Received: 11 January 2011.

Accepted: 10 August 2011. seedling age (Himeda, 1994) and seedling rates (Sasaki, 2004). The seedling length, dry weight, root number, root length, and seedling growth increased significantly by increasing the fertility level in the nursery (Hoshikawa and Ishi, 1974; Singh and Singh, 1998; Raju et al., 2001; Singh et al., 2005). Yield and yield components of rice crop are affected negatively by using a higher seed rate at the nursery level, while yields increase when a lower seeding rate is used in the nursery (Singh et al., 1987). Panda et al. (1991) and Tekrony and Egli (1991) reported more productive tillers and higher yield per unit area by planting healthy and vigorous seedlings grown with sufficient $\mathrm{N}$, which might be due to the decreased mortality rate after transplanting.

The age of seedlings at transplanting is also an important contributor to better performance of rice, which mainly depends on water, labor, herbicides and other inputs. Farmers transplant seedlings at different ages, but most often at 25 to $50 \mathrm{~d}$ old in lowland rice (De Datta, 1981; Wagh et al., 1988; Singh and Singh, 1999). Observations from different researchers, however, have been quite contradictory, but tend to support transplanting seedlings under $20 \mathrm{~d}$. Many researchers have reported that grain yields increase by transplanting seedlings that are younger than 25 d (Mandal et al., 1984; Rao and Raju, 1987; Wagh et al., 1988; Singh and Singh, 1998; Ashraf et al., 1999; Nandini and Singh, 2000; Thanunathan and Sivasubramanian, 2002). Some studies have revealed that grain yield is not affected by transplanting seedlings 
as old as 30-60 d (Chandra and Manna, 1988), whereas, in one study 45-d-old seedlings gave higher yields than seedlings aged 30,60 and $75 \mathrm{~d}$ (Khatun et al., 2002).

Some authors have attributed significantly higher yield and yield components of rice after transplanting younger seedlings (NARC, 2004). Kewat et al. (2002) reported that grain yield decreases after transplanting younger seedlings (14 d), which might be due to the higher mortality rate as compared to that of older seedlings ( $28 \mathrm{~d})$. According to Reddy and Reddy (1992), transplanting 30-d-old seedlings gave more grain yield than 45 and 60 -d-old seedlings. Recent studies on System of Rice Intensification (SRI) also shows that yield and components of yield might be increased by transplanting seedlings as young as 14 $\mathrm{d}$ instead of older seedlings 21-23 d (Makarim et al., 2002). Clear guidelines about seedling age are lacking in existing literature as they have not been clearly identified. SRI recommends transplanting seedlings not older than $15 \mathrm{~d}$, while other guidelines still advise transplanting 20-25-d-old seedlings grown at 4000 seeds $\mathrm{m}^{-2}$ (De Datta, 1981; Mandal et al., 1984). Few researchers have studied the synergistic influence of seedbed management on the characteristics of younger/older seedlings and the consequent impact on plant growth and yield after transplanting. Thus the objectives of this study were to quantify the distinctive effects of nursery management and seedling age on yield and yield components of fine rice.

\section{MATERIALS AND METHODS}

The proposed field study was conducted at the Agronomic Research Farm, Department of Agronomy, University of Agriculture, Faisalabad ( $\left.31^{\circ} 25^{\prime} \mathrm{N}, 7^{\circ} 09^{\prime} \mathrm{E}\right)$, Pakistan, during 2008 and 2009. The experiment was laid out in randomized complete block design with split plot arrangement using three replicates, having a net plot size of $2.20 \mathrm{~m} \times 4 \mathrm{~m}$. The soil texture was sandy clay loam (51.16\% sand, $22.83 \%$ silt, $26.57 \%$ clay) with an average $\mathrm{pH}$ of 7.9 , total soluble salts $0.21 \%$ and organic matter $0.74 \%$. Meteorological data shows (Figure 1) that 2008 was cool and rainy, while in 2009 temperature was high and with less rainfall. The wetland method was used for land preparation and soil was prepared by cultivating it four times with a tractor-drawn cultivator followed by two plankings.

\section{Crop husbandry}

The rice var. Super Basmati was used for nursery-raising with the wet method. Seeds were placed in the form of small heap under gunnysacks and water was sprinkled on the sacks for about $48 \mathrm{~h}$. Then sprouted seeds were broadcasted in the nursery bed in the first week of June, using a high seed rate $\left(D_{1}\right)$ of $4 \mathrm{~kg}$ and a low seed rate $\left(D_{2}\right)$ of $1 \mathrm{~kg} \mathrm{marla}^{-1}$ and with recommended $\mathrm{N}\left(\mathrm{N}_{1}\right)$ and without $\mathrm{N}\left(\mathrm{N}_{0}\right)$. Seedlings were uprooted carefully to avoid root damage from respective nursery beds and transplanted at $10\left(\mathrm{~S}_{1}\right), 20\left(\mathrm{~S}_{2}\right), 30\left(\mathrm{~S}_{3}\right)$ and $40 \mathrm{~d}\left(\mathrm{~S}_{4}\right)$ after germination, corresponding to 15 June, 25 June, 5 July, and 15 July. Two seedlings per hill were planted in puddled soil by keeping row-to-row and plant-to-plant distances of 22 $\mathrm{cm}$. The missing hills were also filled within a week after transplanting to maintain the plant population. Nitrogen at the rate of $140 \mathrm{~kg} \mathrm{ha}^{-1}, 80 \mathrm{~kg} \mathrm{P} \mathrm{ha}^{-1}$ and $60 \mathrm{~kg} \mathrm{~K} \mathrm{ha}^{-1}$ and 10 $\mathrm{kg} \mathrm{Zn} \mathrm{ha}{ }^{-1}$ was applied in the form of urea, diammonium phosphate, sulfate of potash, and zinc sulfate $\left(\mathrm{ZnSO}_{4} 35 \%\right)$ respectively. Whole $\mathrm{P}, \mathrm{K}, \mathrm{Zn}$ and $1 / 3 \mathrm{~N}$ were incorporated into the soil at the time of seedbed preparation, while the remainder was top-dressed in two equal splits at the time of booting and panicle initiation.

Irrigation water at the time of transplanting was maintained at a depth of 3-4 cm. One week after transplanting a constant water depth of 5-6 cm was maintained to keep the field continuously flooded. Irrigation was stopped $1 \mathrm{wk}$ before harvesting, when signs of physiological maturity appeared. For weed control, Butachlor $60 \%$ EC $800 \mathrm{~mL} \mathrm{ha}^{-1}$ was applied at 7 -d of transplanting in standing water (Reddy 2004). Carbofuran $10 \%$ GR was broadcasted at $25 \mathrm{~kg} \mathrm{ha}^{-1}$ at 55 $\mathrm{d}$ after transplanting to protect the plants from borers and leaf folders. Harvesting was done manually at harvest maturity, with approximate seed moisture content of $23 \%$. Threshing was done separately for each plot.

\section{Observations}

At harvest, observations were made regarding agronomic traits and yield components following standard procedures. Collected data were analyzed with Fisher's ANOVA using the MSTAT statistical computer package. The least significant difference (LSD) at 5\% probability was used to compare means of the treatments (Steel et al., 1997).
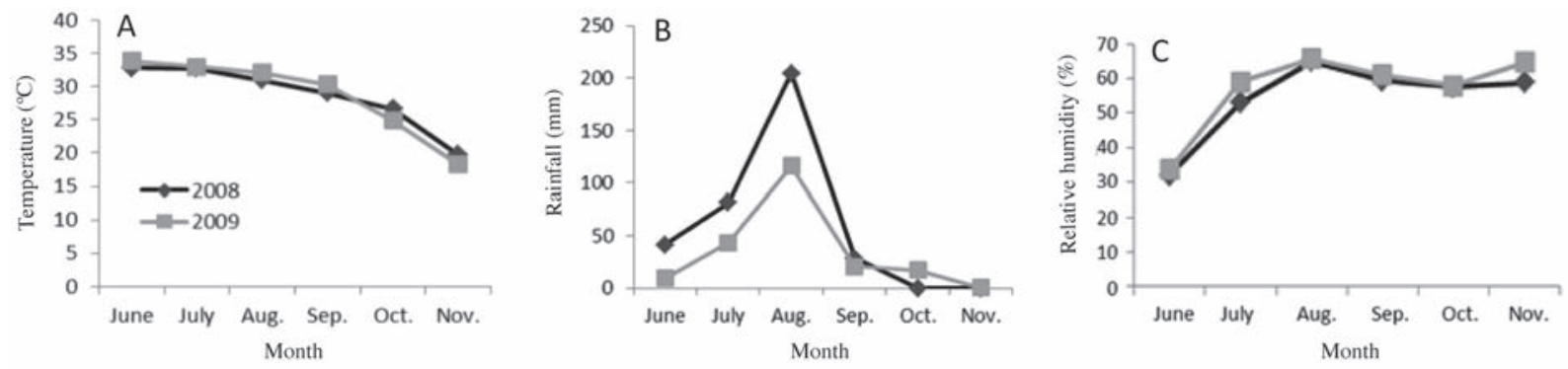

Figure 1. Meteorological data recorded during rice growing seasons. A. Temperature, B. Rainfall and C. Relative humidity. 


\section{RESULTS AND DISCUSSION}

\section{Number of productive tillers}

The data shows that the number of productive tillers $\mathrm{m}^{-2}$ was significantly different according to seedling age, as well as with nursery treatments in both years. Maximum tillers (Table 1) were recorded in $\mathrm{S}_{1}\left(250.58\right.$ tillers $\mathrm{m}^{-2}$ ) with transplanting of 10-d-old seedlings, followed by $\mathrm{S}_{2}$ (220.08 tillers $\left.\mathrm{m}^{-2}\right)$, which was at par with $\mathrm{S}_{3}(206.42$ tillers $\mathrm{m}^{-2}$ ), while $\mathrm{S}_{4}$ produced the minimum tillers (184 tillers $\mathrm{m}^{-2}$ ) in 2008. A similar trend for productive tillers $\left(\mathrm{m}^{-2}\right)$ was recorded in 2009. Overall younger seedlings produced higher numbers of tillers than older seedlings, which might be due to less root damage and minimum transplanting shock, as younger seedlings can more easily establish themselves after transplanting in the main field.

Nursery management also had a significant effect on the number of fertile tillers. Maximum tillers were recorded by transplanting fertile seedlings $\left(\mathrm{D}_{2} \mathrm{~N}_{1}\right)$ grown with the lower seed rate, indicating that a low seed rate with fertilizer application enhances seedling vigor. Interaction between seedling age and nursery management was also found to be significant. The $S_{1}$ produced maximum productive tillers irrespective of seeding densities and $\mathrm{N}$ at nursery seedbed. Treatment $\mathrm{S}_{1} \mathrm{D}_{2} \mathrm{~N}_{1}$ (256.33 tillers $\left.\mathrm{m}^{-2}\right)$ produced the highest productive tillers $\mathrm{m}^{-2}$ as compared to treatments with older seedlings, while it was at par with $\left(\mathrm{S}_{1} \mathrm{D}_{2} \mathrm{~N}_{0}\right.$, $\left.\mathrm{S}_{1} \mathrm{D}_{1} \mathrm{~N}_{1}, \mathrm{~S}_{1} \mathrm{D}_{1} \mathrm{~N}_{0}\right)$. The minimum numbers of tillers were produced in $\mathrm{S}_{4} \mathrm{D}_{1} \mathrm{~N}_{0}\left(165.67\right.$ tillers $\mathrm{m}^{-2}$ ), indicating that high seeding densities with no $\mathrm{N}$ application decrease seedling vigor of nursery seedlings.

A similar trend was observed in the second year of the experiment. Differences in seedling vigor by using higher or lower seeding rates, with or without $\mathrm{N}$ was less with younger seedlings, but was sustained throughout crop growth, with an even wider range with older seedlings at transplantation.

Overall, a higher number of productive tillers was recorded in 2008, which might be due to the favorable weather condition for the rice crop. Our results were in line with Mishra and Salokhe (2008), who reported a higher number of productive tillers after transplanting younger seedlings. They also reported that younger seedlings (12 DAS) enhance tillers per unit area irrespective of seeding densities and fertilizer application at the nursery level. These results are supported by some earlier research that reported positive increases in the number of tillers after transplanting younger seedlings in SRI (Ceesay et al., 2006; Kabir and Uphoff, 2007; Sinha and Talati, 2007).

\section{Plant height}

Plant height is an imperative yield trait that is controlled by the genetic makeup of the plant, as well as growing conditions, seedling vigor, and nutrient status. Figure 2 shows that in 2008, plant height increased significantly by planting younger seedlings as compared to older
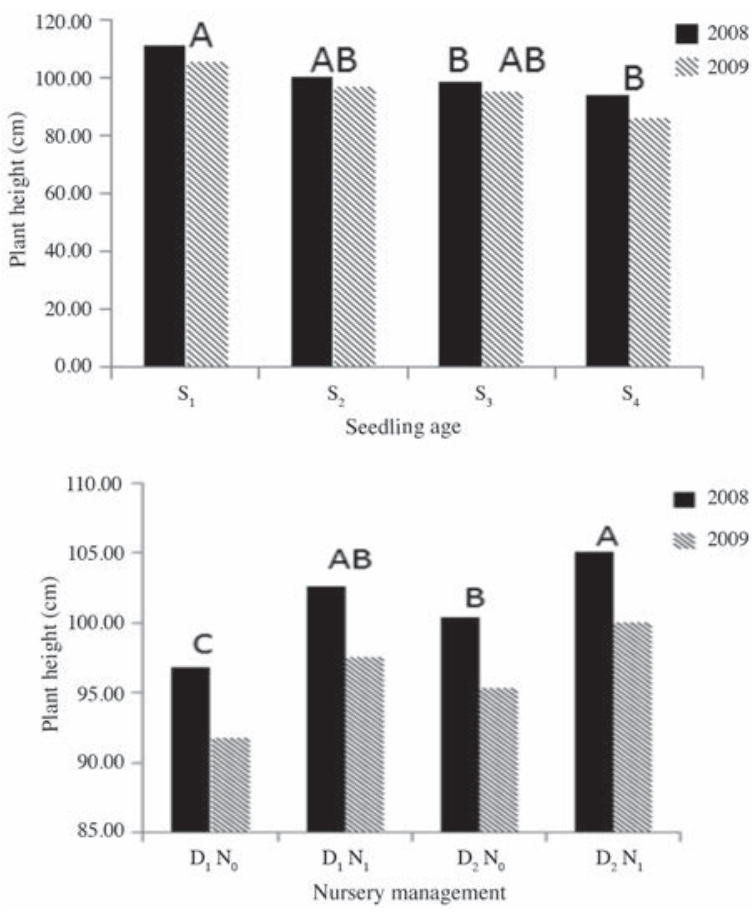

$\mathrm{LSD}_{0.05}$ (seedling age) $2008=11.225 ; \mathrm{LSD}_{0.05}$ (seedling age) $2009=11.423 ; \mathrm{LSD}_{0.05}$ (nursery management) $2008=2.676 ; \mathrm{LSD}_{0.05}$ (nursery management) $2009=2.88 . \mathrm{LSD}_{0.05}$ : least significant difference at $5 \%$ probability.

$\mathrm{S}_{1}=10-\mathrm{d}, \mathrm{S}_{2}=20-\mathrm{d}, \mathrm{S}_{3}=30-\mathrm{d}, \mathrm{S}_{4}=40-\mathrm{d} ; \mathrm{D}_{1} \mathrm{~N}_{0}$ : High seeding density without $\mathrm{N} ; \mathrm{D}_{1} \mathrm{~N}_{1}$ : High seeding density with $\mathrm{N} ; \mathrm{D}_{2} \mathrm{~N}_{0}$ : Low seeding density without $\mathrm{N}$; and $\mathrm{D}_{2} \mathrm{~N}_{1}$ : Low seeding density with $\mathrm{N}$

Figure 2. Plant height as affected by nursery seeding density, N, and seedling age in transplanted fine rice during 2008 and 2009.

Table 1. Number of reproductive tillers as affected by nursery seeding density, nitrogen and seedling age in transplanted fine rice during 2008 and 2009.

\begin{tabular}{|c|c|c|c|c|c|c|c|c|c|c|}
\hline \multirow[b]{3}{*}{ NM } & \multicolumn{5}{|c|}{2008} & \multicolumn{5}{|c|}{2009} \\
\hline & \multicolumn{5}{|c|}{ Seedling age } & \multicolumn{5}{|c|}{ Seedling age } \\
\hline & $\mathrm{S}_{1}$ & $\mathrm{~S}_{2}$ & $\mathrm{~S}_{3}$ & $\mathrm{~S}_{4}$ & Mean & $\mathrm{S}_{1}$ & $\mathrm{~S}_{2}$ & $\mathrm{~S}_{3}$ & $\mathrm{~S}_{4}$ & Mean \\
\hline $\mathrm{D}_{1} \mathrm{~N}_{0}$ & $244.7 \mathrm{ab}$ & $211.7 \mathrm{def}$ & $195.7 \mathrm{fg}$ & $165.7 \mathrm{~h}$ & $204.4 c$ & $241.0 \mathrm{abc}$ & $201.7 \mathrm{e}$ & $191.3 \mathrm{e}$ & $133.0 \mathrm{~g}$ & $191.8 \mathrm{c}$ \\
\hline $\mathrm{D}_{1} \mathrm{~N}_{1}$ & $252.3 \mathrm{ab}$ & $216.7 \mathrm{de}$ & $205.7 \mathrm{def}$ & $180.0 \mathrm{~g}$ & $213.7 b$ & $258.3 \mathrm{ab}$ & 216.0 cde & $213.0 \mathrm{e}$ & $159.3 \mathrm{f}$ & $211.7 \mathrm{~b}$ \\
\hline $\mathrm{D}_{2} \mathrm{~N}_{0}$ & $249.0 \mathrm{ab}$ & 218.7cde & 204.3ef & $179.0 \mathrm{fg}$ & $212.8 b$ & $247.7 \mathrm{a}$ & $212.7 \mathrm{de}$ & $203.0 \mathrm{e}$ & $153.0 \mathrm{~g}$ & $204.1 b$ \\
\hline $\mathrm{D}_{2} \mathrm{~N}_{1}$ & $256.3 \mathrm{a}$ & $233.3 \mathrm{bbc}$ & $220.0 \mathrm{~cd}$ & 211.3def & $230.3 \mathrm{a}$ & $258.0 \mathrm{a}$ & $227.3 \mathrm{~cd}$ & $212.0 \mathrm{e}$ & $210.3 \mathrm{e}$ & $226.9 \mathrm{a}$ \\
\hline Mean & $250.6 \mathrm{a}$ & $220.1 \mathrm{~b}$ & $206.4 b$ & $184.0 \mathrm{c}$ & & $226.9 a$ & $204.1 b$ & $211.7 \mathrm{~b}$ & $191.8 \mathrm{c}$ & \\
\hline
\end{tabular}

$\mathrm{LSD}_{0.05}$ (seedling age) $2008=15.698 ; \mathrm{LSD}_{0.05}$ (nursery management) $2008=7.46 ; \mathrm{LSD}_{0.05}$ (seedling age $\times$ nursery management) 2008 = 14.929; LSD 0.05 (seedling age) 2009 = 16.329; LSD 0.05 (nursery management) $2008=11.832 ;$ LSD $_{0.05}$ (seedling age $\times$ nursery management) $2008=23.663$. LSD $\mathrm{D}_{0.05}$ : least significant difference at $5 \%$ probability; NM: Nursery management (seeding density and $\mathrm{N}$ ).

$\mathrm{D}_{1} \mathrm{~N}_{0}$ : High seeding density without $\mathrm{N} ; \mathrm{D}_{1} \mathrm{~N}_{1}$ : High seeding density with $\mathrm{N} ; \mathrm{D}_{2} \mathrm{~N}_{0}$ : Low seeding density without $\mathrm{N}$; and $\mathrm{D}_{2} \mathrm{~N}_{1}$ : Low seeding density with $\mathrm{N}$. 
seedlings. The maximum plant height was recorded in the $\mathrm{S}_{1}$ treatment with younger seedling (10-d), which is at par with $S_{2}(20-d)$, but significantly higher than with $S_{3}$ and $S_{4}$ which were at par with each other. Similar observations were recorded in the second year regarding seedling age and nursery management. This might be due to higher phyllocrone production in younger seedlings before entering to reproductive stage, as well as less transplanting shock at this stage. These results are supported by Mishra and Salokhe (2008), who recorded more plant height after transplanting younger seedlings (12-d), as compared to older (30-d) seedlings.

Regarding nursery management treatments, seedling grown with low seeding densities and fertilizer application produced significantly taller plants than seedlings grown with high seedling density and without fertilizer. This might be due to the healthy and vigorous start, as there was less seedling competition in nursery with the lower seeding rate, and with sufficient nutrients. Our results are in agreement with Mishra and Salokhe (2008), who observed that the fertilizer application at the nursery stage is a crucial factor in increasing seedling vigor. Farooq et al. (2007) also observed an increasing trend in plant height after transplanting improved nursery seedlings.

\section{0-Grain weight}

1000-Grain weight is an important yield contributor that depends on genetic makeup and is the least affected by growing conditions (Ashraf et al., 1999). In 2008, younger seedlings had higher 1000-grain weight as compared to older seedlings (Figure 3). Maximum weight was given by $\mathrm{S}_{1}(21.43 \mathrm{~g})$, which was at par with $\mathrm{S}_{2}(18.78 \mathrm{~g})$, but significantly higher than $\mathrm{S}_{3}(15.54 \mathrm{~g})$ and $\mathrm{S}_{4}(14.8 \mathrm{~g})$.

As regarding nursery management treatments, heavier grains were recorded in $\mathrm{D}_{2} \mathrm{~N}_{1}(19.33 \mathrm{~g})$ by transplanting seedlings grown with low seeding densities and with fertilizer application followed by $\mathrm{D}_{1} \mathrm{~N}_{1}(18.05 \mathrm{~g})$ and $\mathrm{D}_{2} \mathrm{~N}_{0}(17.36 \mathrm{~g})$, which were at par with each other. The minimum 1000-grain weight was recorded in $\mathrm{D}_{1} \mathrm{~N}_{0}(15.82$ g) with transplanting nursery grown seedlings with high seeding density and without $\mathrm{N}$ application. A similar trend for 1000-grain weight was recorded in 2009. This might be due to the transplanting of vigorous seedlings with better root growth and more leaves produced at lower seedling density with fertilizer application. Lal and Roy (1996) explained that seedling vigor was improved in terms of root length, height and leaf area of seedlings at the time of transplanting by seeding densities and nutrient applied in the nursery. Our results were also supported by Rao and Raju (1987), who reported that 1000-grain weight increased by transplanting younger seedlings (25d) as compared to older seedlings (45 d). Panda et al. (1991) also observed an increasing trend in grain weight by transplanting seedlings grown with sufficient fertilizer application. In contrast, Gill and Sahi (1987) stated that transplanting of $60-\mathrm{d}$ old seedlings yielded heavier
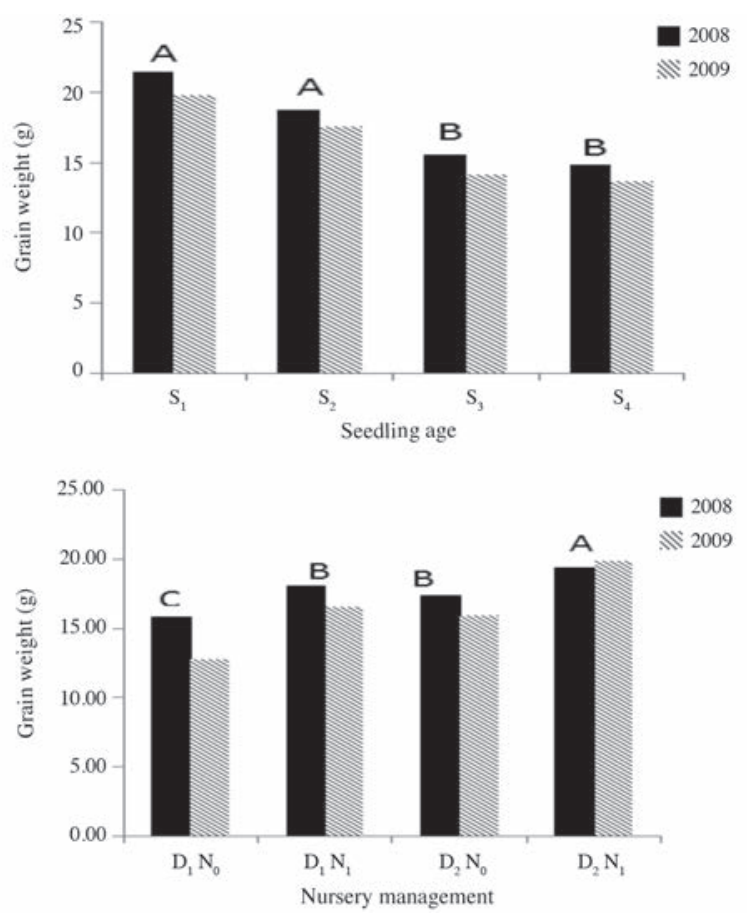

LSD $_{0.05}$ (seedling age) $2008=2.623 ; \operatorname{LSD}_{0.05}$ (seedling age) $2009=2.312 ;$ LSD $_{0.05}$ (nursery management) $2008=1.32 ;$ LSD $_{0.05}$ (nursery management) $2009=2.116$. LSD $_{0.05}$ : least significant difference at $5 \%$ probability.

$\mathrm{S}_{1}=10-\mathrm{d} ; \mathrm{S}_{2}=20$-d; $\mathrm{S}_{3}=30$-d; $\mathrm{S}_{4}=40$-d; $\mathrm{D}_{1} \mathrm{~N}_{0}$ : High seeding density without $\mathrm{N}_{2} ; \mathrm{D}_{1} \mathrm{~N}_{1}$ : High seeding density with $\mathrm{N} ; \mathrm{D}_{2} \mathrm{~N}_{0}$ : Low seeding density without $\mathrm{N}$; and $\mathrm{D}_{2} \mathrm{~N}_{\mathrm{I}}$ : Low seeding density with $\mathrm{N}$.

Figure 3. 1000-grain weight (g) as affected by nursery seeding density, N, and seedling age in transplanted fine rice during 2008 and 2009.

1000-grain. Farooq et al. (2007) reported no significant difference in 1000-grain weight by planting healthy seedlings grown with seed priming.

\section{Straw yield}

The data pertaining to straw yield are presented in Table 2 , which shows that all treatments significantly increased straw yield in both years. In 2008, maximum straw yield was recorded by transplanting younger seedling $\mathrm{S}_{1}\left(11.04 \mathrm{t} \mathrm{ha}^{-1}\right)$, followed by $\mathrm{S}_{2}\left(10.30 \mathrm{t} \mathrm{ha}^{-1}\right)$ and the minimum straw yield was recorded in treatment $\mathrm{S} 4$ (8.90 $\mathrm{t} \mathrm{ha}^{-1}$ ) with transplanting of older seedlings (40-d). As regarding nursery treatments, maximum straw yield was found in $\mathrm{D}_{2} \mathrm{~N}_{1}\left(10.70 \mathrm{t} \mathrm{ha}^{-1}\right)$ by transplanting seedlings grown with low seeding densities and adequate fertilizer, while the minimum value $\left(10.70 \mathrm{t} \mathrm{ha}^{-1}\right)$ was recorded by transplanting seedlings grown with high seeding density and starved of fertilizer application. This might be due to the higher $\mathrm{N}$ content in seedlings and a lower mortality rate at transplanting in the main field, which gave an improved start. Our results concur with Ros et al. (2003) and Singh et al. (2005) who reported greater $\mathrm{N}$ contents and straw yield in fertile nursery. Combined effect of seedling age with nursery management was also significant.

In 2008 , the maximum value was recorded in $\mathrm{S}_{1} \mathrm{D}_{2} \mathrm{~N}_{1}$ 
Table 2. Straw yield $\left(\mathrm{t} \mathrm{ha}^{-1}\right)$ as affected by nursery seeding density, $\mathrm{N}$, and seedling age in transplanted fine rice during 2008 and 2009.

\begin{tabular}{|c|c|c|c|c|c|c|c|c|c|c|}
\hline \multirow[b]{3}{*}{ NM } & \multicolumn{5}{|c|}{2008} & \multicolumn{5}{|c|}{2009} \\
\hline & \multicolumn{5}{|c|}{ Seedling age } & \multicolumn{5}{|c|}{ Seedling age } \\
\hline & $\mathrm{S}_{1}$ & $\mathrm{~S}_{2}$ & $\mathrm{~S}_{3}$ & $\mathrm{~S}_{4}$ & Mean & $\mathrm{S}_{1}$ & $\mathrm{~S}_{2}$ & $\mathrm{~S}_{3}$ & $\mathrm{~S}_{4}$ & Mean \\
\hline $\mathrm{D}_{1} \mathrm{~N}_{0}$ & $10.9 \mathrm{abc}$ & $9.8 \mathrm{ef}$ & $8.3 \mathrm{~h}$ & $8.7 \mathrm{gh}$ & $9.4 \mathrm{~d}$ & $10.4 \mathrm{ab}$ & $9.4 \mathrm{~cd}$ & $7.8 f$ & $8.1 \mathrm{f}$ & $8.9 \mathrm{~d}$ \\
\hline $\mathrm{D}_{1} \mathrm{~N}_{1}$ & $11.1 \mathrm{ab}$ & $10.3 \mathrm{cde}$ & $10.4 \mathrm{~b} \sim \mathrm{e}$ & $8.6 \mathrm{~h}$ & $10.1 \mathrm{~b}$ & $10.6 \mathrm{ab}$ & $9.9 \mathrm{c}$ & $9.9 \mathrm{~cd}$ & $8.0 \mathrm{f}$ & $9.6 \mathrm{~b}$ \\
\hline $\mathrm{D}_{2} \mathrm{~N}_{0}$ & $11.0 \mathrm{abc}$ & 10.1def & $9.4 \mathrm{fg}$ & $8.5 \mathrm{~h}$ & $9.7 \mathrm{c}$ & $10.5 \mathrm{ab}$ & $9.7 \mathrm{~cd}$ & $8.9 \mathrm{e}$ & $7.9 \mathrm{f}$ & $9.2 \mathrm{c}$ \\
\hline $\mathrm{D}_{2} \mathrm{~N}_{1}$ & $11.2 \mathrm{a}$ & $11.1 \mathrm{ab}$ & $10.7 \mathrm{bcd}$ & $9.8 \mathrm{ef}$ & $10.7 \mathrm{a}$ & $10.7 \mathrm{a}$ & $10.7 \mathrm{ab}$ & $10.2 \mathrm{bc}$ & $9.2 \mathrm{e}$ & $10.2 \mathrm{a}$ \\
\hline Mean & $11.0 \mathrm{a}$ & $10.3 b$ & $9.7 \mathrm{c}$ & $8.9 \mathrm{~d}$ & & $10.5 \mathrm{a}$ & $9.9 \mathrm{~b}$ & $9.2 \mathrm{c}$ & $8.3 \mathrm{~d}$ & \\
\hline
\end{tabular}

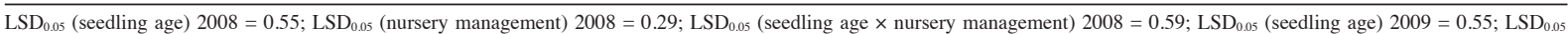
(nursery management) $2009=0.29 ; \mathrm{LSD}_{0.05}$ (seedling age $\times$ nursery management) $2009=0.59$. LSD 0.05 : least significant difference at $5 \%$ probability; NM: Nursery management (seeding density and $\mathrm{N}$ ).

$\mathrm{D}_{1} \mathrm{~N}_{0}$ : High seeding density without $\mathrm{N} ; \mathrm{D}_{1} \mathrm{~N}_{1}$ : High seeding density with $\mathrm{N} ; \mathrm{D}_{2} \mathrm{~N}_{0}$ : Low seeding density without $\mathrm{N}$; and $\mathrm{D}_{2} \mathrm{~N}_{1}$ : Low seeding density with $\mathrm{N}$.

(11.20 $\mathrm{t} \mathrm{ha}^{-1}$ ) by transplanting younger seedlings grown with low seeding densities and sufficient fertilizer, while the minimum value was found in $\mathrm{S}_{4} \mathrm{D}_{1} \mathrm{~N}_{0}\left(8.73 \mathrm{t} \mathrm{ha}^{-1}\right)$, transplanting older seedlings grown with high seeding densities and without $\mathrm{N}$ application. A similar trend was observed in the second year of experimentation. Data also shows that $S_{1}$ increased straw yield linearly, irrespective of seeding densities and fertilizer as compared to other seedlings. The effect of seeding densities and fertilizer was more pronounced at later stages after planting older seedlings. This is in agreement with Panda et al. (1991) and Ros et al. (2003).

\section{Paddy yield}

Data show that seedling age and nursery management significantly increased yield in both years (Table 3). Among seedling age, in 2008, maximum yield was recorded in $S_{1}\left(3.78 \mathrm{tha}^{-1}\right)$, followed by $\mathrm{S}_{2}\left(3.19 \mathrm{t} \mathrm{ha}^{-1}\right)$ while the minimum value was found by $\mathrm{S}_{4}\left(2.28 \mathrm{tha}^{-1}\right)$. As regarding nursery management, maximum paddy yield was recorded in $\mathrm{D}_{2} \mathrm{~N}_{1}\left(3.37 \mathrm{tha}^{-1}\right)$ followed by $\mathrm{D}_{1} \mathrm{~N}_{1}(2.99$ $\left.\mathrm{t} \mathrm{ha}^{-1}\right)$, while the minimum yield was given by $\mathrm{D}_{1} \mathrm{~N}_{0}(2.68$ $\left.t \mathrm{tha}^{-1}\right)$. The combined effect of seedling age with nursery management was also found to be significant in both the years. In 2008 maximum paddy yield was recorded in $\mathrm{S}_{1} \mathrm{D}_{2} \mathrm{~N}_{1}\left(4.05 \mathrm{t} \mathrm{ha}^{-1}\right)$, which was significantly higher than all other treatments, while in 2009 maximum value recorded in $\mathrm{S}_{1} \mathrm{D}_{2} \mathrm{~N}_{1}\left(3.61 \mathrm{tha}^{-1}\right)$, which was at par with $\mathrm{S}_{1} \mathrm{D}_{2} \mathrm{~N}_{0}\left(3.46 \mathrm{t} \mathrm{ha}^{-1}\right), \mathrm{S}_{1} \mathrm{D}_{1} \mathrm{~N}_{1}\left(3.49 \mathrm{tha}^{-1}\right), \mathrm{S}_{1} \mathrm{D}_{1} \mathrm{~N}_{0}$ $\left(3.41 \mathrm{tha}^{-1}\right)$ and $\mathrm{S}_{2} \mathrm{D}_{2} \mathrm{~N}_{1}\left(3.41 \mathrm{tha}^{-1}\right)$.

Rice plants grown from seedlings raised at low seeding densities and sufficient $\mathrm{N}$ fertilizer performed better than the rice plants grown from seedlings raised at high seeding densities without $\mathrm{N}$ application. Our findings concur with reports of earlier research (Panda et al., 1991; Lal and Roy, 1996; Singh et al., 2005). Overall higher yield was found after transplanting seedlings as young as 10-d compared to yields with 20,30 and 40-d-old seedlings, which might be due to the increase in all yield attributes at this stage. Grain yield was consistently reduced with older seedlings, which is associated with lower yield attributes. Data also shows that 10-d nursery transplanting increased yield, irrespective of nursery treatments, which might be due to the easier establishment of younger seedlings after transplanting because they suffer less root damage during uprooting, with minimum transplanting shock and mortality rate, which increases all yield attributes of transplanted rice. These findings confirm some earlier studies on younger seedlings (Mandal et al., 1984; Rao and Raju, 1987; Wagh et al., 1988, Ashraf et al., 1999; Raju et al., 2001; Horie et al., 2005; Mishra and Salokhe, 2008; Pasuquin et al., 2008). These findings also show the potential of younger seedlings in SRI and illustrate that by making a small additional investment in raising healthy and vigorous seedlings in nursery seedbed; farmers can increase yield benefits. Skill in handling younger seedlings can be acquired with practice and this could be become appreciated for the impact it can have on crop profitability.

\section{Harvest index}

All treatments had significant effects on harvest indices in both years. Comparison of mean values (Figure 4) shows that the maximum harvest index $(25.47 \%)$ was recorded with transplanting younger seedlings (10d) and the minimum value $(20.37 \%)$ was found in $S_{4}$

Table 3. Paddy yield $\left(\mathrm{t} \mathrm{ha}^{-1}\right)$ as affected by nursery seeding density, $\mathrm{N}$, and seedling age in transplanted fine rice during 2008 and 2009.

\begin{tabular}{|c|c|c|c|c|c|c|c|c|c|c|}
\hline \multirow[b]{3}{*}{ NM } & \multicolumn{5}{|c|}{2008} & \multicolumn{5}{|c|}{2009} \\
\hline & \multicolumn{5}{|c|}{ Seedling age } & \multicolumn{5}{|c|}{ Seedling age } \\
\hline & $\mathrm{S}_{1}$ & $\mathrm{~S}_{2}$ & $\mathrm{~S}_{3}$ & $\mathrm{~S}_{4}$ & Mean & $\mathrm{S}_{1}$ & $\mathrm{~S}_{2}$ & $\mathrm{~S}_{3}$ & $\mathrm{~S}_{4}$ & Mean \\
\hline $\mathrm{D}_{1} \mathrm{~N}_{0}$ & $3.6 b$ & $3.0 \mathrm{~cd}$ & $2.1 \mathrm{e}$ & $2.0 \mathrm{e}$ & $2.7 \mathrm{c}$ & $3.4 \mathrm{a}$ & $2.8 \mathrm{bcd}$ & $1.9 \mathrm{e}$ & $1.8 \mathrm{e}$ & $2.5 \mathrm{c}$ \\
\hline $\mathrm{D}_{1} \mathrm{~N}_{1}$ & $3.8 \mathrm{~b}$ & $3.1 \mathrm{c}$ & $2.8 \mathrm{~cd}$ & $2.2 \mathrm{e}$ & $3.0 \mathrm{~b}$ & $3.5 \mathrm{a}$ & $3.0 \mathrm{~b}$ & $2.6 \mathrm{~cd}$ & $2.0 \mathrm{~cd}$ & $2.8 \mathrm{~b}$ \\
\hline $\mathrm{D}_{2} \mathrm{~N}_{0}$ & $3.7 \mathrm{~b}$ & $3.1 \mathrm{c}$ & $2.3 \mathrm{e}$ & $2.1 \mathrm{e}$ & $2.8 \mathrm{c}$ & $3.5 \mathrm{a}$ & $2.9 \mathrm{bc}$ & $2.1 \mathrm{e}$ & $1.9 \mathrm{e}$ & $2.6 \mathrm{c}$ \\
\hline $\mathrm{D}_{2} \mathrm{~N}_{1}$ & $4.0 \mathrm{a}$ & $3.6 \mathrm{~b}$ & $3.1 \mathrm{c}$ & $2.7 \mathrm{~d}$ & $3.4 \mathrm{a}$ & $3.6 \mathrm{a}$ & $3.4 \mathrm{a}$ & $2.9 \mathrm{bc}$ & $2.5 \mathrm{bc}$ & $3.1 \mathrm{a}$ \\
\hline Mean & $3.8 \mathrm{a}$ & $3.2 \mathrm{~b}$ & $2.6 \mathrm{c}$ & $2.3 \mathrm{~d}$ & & $3.5 \mathrm{a}$ & $3.0 \mathrm{~b}$ & $2.4 \mathrm{c}$ & $2.0 \mathrm{~d}$ & \\
\hline
\end{tabular}

$\mathrm{LSD}_{0.05}$ (seedling age) $2008=0.271 ; \mathrm{LSD}_{0.05}$ (nursery management) $2008=0.126 ; \mathrm{LSD}_{0.05}$ (seedling age $\times$ nursery management) $2009=0.252 ; \mathrm{LSD}_{0.05}\left(\mathrm{seedling}\right.$ age) $2009=0.27 ; \mathrm{LSD}_{0.05}$ (nursery management) $2009=0.13 ;$ LSD $_{0.05}$ (seedling age $\times$ nursery management) $2009=0.25$. LSD $_{0.05}$ : least significant difference at $5 \%$ probability; NM: Nursery management (seeding density and $\mathrm{N}$ ).

$\mathrm{D}_{1} \mathrm{~N}_{0}$ : High seeding density without $\mathrm{N} ; \mathrm{D}_{1} \mathrm{~N}_{1}$ : High seeding density with $\mathrm{N} ; \mathrm{D}_{2} \mathrm{~N}_{0}$ : Low seeding density without $\mathrm{N}$; and $\mathrm{D}_{2} \mathrm{~N}_{1}$ : Low seeding density with $\mathrm{N}$. 

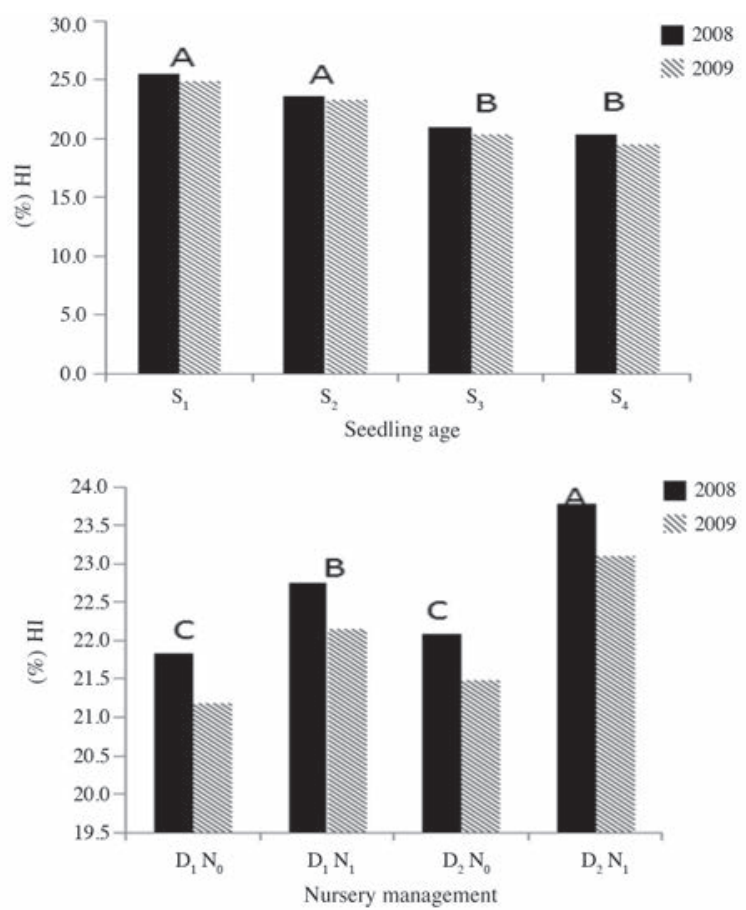

$\mathrm{LSD}_{0.05}$ (seedling age) $2008=0.88 ; \mathrm{LSD}_{0.05}$ (seedling age) $2009=0.93 ; \mathrm{LSD}_{0.05}$ (nursery management) $2008=0.73 ; \operatorname{LSD}_{0.05}$ (nursery management) $2009=0.77 ; \mathrm{LSD}_{0.05}$ : least significant difference at $5 \%$ probability.

$\mathrm{S}_{1}=10$-d; $\mathrm{S}_{2}=20$-d; $\mathrm{S}_{3}=30$-d; $\mathrm{S}_{4}=40$-d; $\mathrm{D}_{1} \mathrm{~N}_{0}$ : High seeding density without $\mathrm{N} ; \mathrm{D}_{1} \mathrm{~N}_{1}$ High seeding density with $\mathrm{N} ; \mathrm{D}_{2} \mathrm{~N}_{0}$ : Low seeding density without $\mathrm{N}$; and $\mathrm{D}_{2} \mathrm{~N}_{1}$ : Low seeding density with $\mathrm{N}$.

Figure 4. Harvest index (HI) as affected by nursery seeding density, N, and seedling age in transplanted fine rice during 2008 and 2009.

where transplanting was done with older seedlings (40d). The higher harvest index in $S_{1}$ was due to the higher yield recorded in that treatment. Regarding nursery management, comparison of mean values shows that the maximum harvest index was recorded in $\mathrm{D}_{2} \mathrm{~N}_{1}(23.79 \%)$ after transplanting the seedlings grown with a low seeding rate and sufficient nutrient, followed by $\mathrm{D}_{1} \mathrm{~N}_{1}(22.75 \%)$, which was at par with $\mathrm{D}_{2} \mathrm{~N}_{0}(22.09 \%)$. The minimum value was recorded in $\mathrm{D}_{1} \mathrm{~N}_{0}(21.84 \%)$, with seedlings grown with high a seeding rate and without fertilizer, which was also at par with the treatment $\mathrm{D}_{2} \mathrm{~N}_{0}(22.09 \%)$. Overall, fertile seedlings produced higher harvest index as compared to the other treatments. A similar trend was recorded the second year of the experiment.

\section{CONCLUSIONS}

It is concluded that transplanting younger seedlings (10d) produced maximum yield, irrespective of nursery management, while significant interaction was found at later stages. Transplanting 20-d old fertile seedlings grown at low seeding density produced similar yields to transplanting younger seedlings grown at higher densities than the older seedlings, while the lowest yield was found in older seedlings grown with high seeding density and without $\mathrm{N}$ fertilizer application.
Impacto de la densidad de siembra en vivero, nitrógeno, y edad de plántula sobre rendimiento $\mathbf{y}$ atributos de rendimiento de arroz fino. La producción de plántulas vigorosas y el trasplante en la edad adecuada son los factores más importantes para obtener buenos rendimientos en arroz (Oryza sativa L.). El impacto de la siembra, densidades, N, y edad de las plántulas fue evaluado en este experimento después del trasplante de plántulas de 10, 20,30 y 40 d cultivadas usando diferentes densidades de siembra (alta y baja) y condiciones de $\mathrm{N}$ (con y sin) en el cultivo del arroz temporadas 2008 y 2009. Independiente de la densidad de siembra y la aplicación de fertilizantes, plántulas de vivero de 10 -d presentaron mayores rendimientos y componentes de rendimiento (tallos productivos, altura de planta, peso de 1000 granos, y rendimiento de paja), mientras que en etapas posteriores se observó una interacción significativa con el manejo de vivero. El trasplante de plántulas fértiles de 20 d cultivadas con baja densidad de siembra en la cama del vivero, se tradujo en un mayor número de macollos productivos $\mathrm{m}^{-2}(233,3 ; 227,3)$, producción de paja $\left(11,1 ; 10,7 \mathrm{t} \mathrm{ha}^{-1}\right)$, y rendimiento final $\left(3,6 ; 3,4 \mathrm{t} \mathrm{ha}^{-1}\right)$, en los años $2008 \mathrm{y}$ 2009 respectivamente. Los atributos de rendimiento y el rendimiento se redujeron significativamente después del trasplante plántulas mayores cultivadas con alta densidad de siembra y sin fertilizante en vivero. Producción de macollos $(165,7 ; 133)$, rendimiento de paja $(8,7 ; 8,1$ $\left.\mathrm{t} \mathrm{ha}^{-1}\right)$ y rendimiento de arroz $\left(2,0 ; 1,8 \mathrm{t} \mathrm{ha}^{-1}\right)$ mínimos se registraron con trasplante de plántulas mayores de 40 d cultivadas con alta de densidad de siembra y sin aplicación de N. Estos hallazgos sustentan el uso de plántulas jóvenes en un sistema de intensificación de arroz e ilustran que con una pequeña inversión adicional en el cultivo de plántulas sanas y vigorosas en la cama de semillas del vivero, los agricultores pueden aumentar los rendimientos.

Palabras clave: arroz, vivero, edad de los cultivos de plántulas y rendimiento, Oryza sativa.

\section{LITERATURE CITED}

Ashraf, M., A. Khalid, and K. Ali. 1999. Effect of seedling age and density on growth and yield of rice in saline soil. Pakistan Journal of Biology Science 2:860-862.

Ceesay, M., S.W. Reid, E.C.M. Fernandes, and N.T. Uphoff. 2006. The effect of repeated soil wetting and drying on low land rice yield with System of Rice Intensification (SRI) methods. International Journal of Agricultural Sustainability 4:5-14.

Chandra, D., and G.B. Manna. 1988. Effect of planting date, seedling age, and planting density in late planted wet season rice. International Rice Research Notes (IRRN) 13(6):30.

De Datta, S.K. 1981. Principles and practices of rice production. Wiley \& Sons, Singapore.

Farooq, M., S.M.A. Basra, and N. Ahmad. 2007. Improving the performance of transplanted rice by seed priming. Plant Growth Regulation 51:129-137.

Federal Bureau of Statistics. 2008. Pakistan statistical year book 2008. Federal Bureau of Statistics, Statistics Division, Government of Pakistan, Islamabad, Pakistan. 
Federal Bureau of Statistics. 2009. Pakistan statistical year book 2009. Federal Bureau of Statistics, Statistics Division, Government of Pakistan, Islamabad, Pakistan.

Gill, P.S., and H.N. Sahi. 1987. Effect of nitrogen levels in relation to age of seedlings and milling characteristics of rice. Indian Journal of Agricultural Science 57:630-634.

Himeda, M. 1994. Cultivation technique of rice nurseling seedlings: Review of research papers and its future implementation. Agriculture and Horticulture 69:679-683, 791-796.

Horie, T., T. Shiraiwa, K. Homma, Y. Maeda, and H. Yoshida. 2005. Can yields of lowland rice resume the increases that they showed in the 1980s? Plant Production Science 8:251-272.

Hoshikawa, K., and R. Ishi. 1974. Gas exchange characteristics of 'young' rice seedlings raised in box. Proceedings of Crop Science Society of Japan 43:5-6.

Kabir, H., and N. Uphoff. 2007. Results of disseminating the system of rice intensification with farmer field school methods in Northern Myanmar. Experimental Agriculture 43:463-476.

Kewat, M.L., S.B. Agrawal, K.K. Agrawal, and R.S. Sharma. 2002. Effect of divergent plant spacings and age of seedlings on yield and economics of hybrid rice (Oryza sativa). Indian Journal of Agronomy 47:367-371.

Khatun, A., M.I.U. Mollah, I.H. Rashid, M.S. Islam, and A.H. Khan. 2002. Seasonal effect of seedling age on the yield of rice. Pakistan Journal of Biological Sciences 5:40-42.

Lal, M., and R.K. Roy. 1996. Effect of nursery seeding density and fertilizer on seedling growth and yield of rice (Oryza sativa). Indian Journal of Agronomy 41:642-644.

Makarim, A.K., V. Balasubramanian, Z. Zaini, I. Syamsiah, I.G.P.A. Diratmadja, A. Handoko, et al. 2002. Systems of rice intensification (SRI): evaluation of seedling age and selected components in Indonesia. p. 129-139. In Bouman, B.A.M., A. Hengsdijk, B. Hardy, P.S. Bindraban, T.P. Tuong, and J.K. Ladha (eds.) International Workshop on Water-Wise Rice Production, Los Baños, Phillipines. 8-11 April 2002. International Rice Research Institute IRRI, Los Baños, Phillipines.

Mandal, B.K., T.R. Sainik, and P.K. Ray. 1984. Effect of age of seedling and level of nitrogen on the productivity of rice. Oryza $21: 225-232$

Mishra, A., and V.M. Salokhe. 2008. Seedling characteristics and the early growth of transplanted rice under different water regimes. Experimental Agriculture 44:365-383.

Nandini, D.K., and A.I. Singh. 2000. Influence of seedling age and plant density on the performance of rice. Central Agricultural University, College of Agriculture, Imphal, Manipur, India.

NARC. 2004. Nepal Annual Report 9900. Available at http://www. narc.nepal.org/Highlights/Annreport 9900/RICE.htm (accessed November 2010).

Padalia, C.R. 1980. Effect of age of seedling on the growth and yield of transplanted rice. Oryza 81:165-167.
Panda, M.M., M.D. Reddy, and A.R. Sharma. 1991. Yield performance of rainfed lowland rice as affected by nursery fertilization under conditions of intermediate deep water (15-50 $\mathrm{cm})$ and flash flood. Plant and Soil 132:65-71.

Pasuquin, E., T. Lafarge, and B. Tubana. 2008. Transplanting young seedlings in irrigated rice fields: Early and high tiller production enhanced grain yield. Field Crop Research 105:141-155.

Raju, R.A., M.N. Reddy, and B. Gangwar. 2001. Nursery fertilization of rice (Oryza sativa) with native weed vegetation. Indian Journal of Agronomy 46:94-100.

Rao, C.P., and M.S. Raju. 1987. Effect of age of seedling, nitrogen and spacing on rice. Indian Journal of Agronomy 32:100-102.

Reddy, S. 2004. Agronomy of field crops. Kalyani Publishers, New Delhi, India.

Reddy, K.S., and B.B. Reddy. 1992. Effect of transplanting time, plant density and seedling age on growth and yield of rice. Indian Journal of Agronomy 37:18-21.

Ros, C., R.W. Bell, and P.F. White. 2003. Seedling vigour and the early growth of transplanted rice (Oryza sativa). Plant and Soil 252:325-337.

Sasaki, R. 2004. Characteristics and seedlings establishment of rice nurseling seedlings. Japanese Agricultural Research Quarterly 38:7-13.

Sinha, S.K., and J. Talati. 2007. Productivity impacts of the system of rice intensification (SRI): A case study in West Bengal, India. Agricultural Water Management 87:55-60.

Singh, K.N., B. Hassan, B.A. Kanday, and A.K. Bhat. 2005. Effect of nursery fertilization on seedling growth and yield of rice (Oryza sativa). Indian Journal of Agronomy 50:187-189.

Singh, O.P., D. Pal, and H. Om. 1987. Effect of seed rate in nursery and seedlings/hill on the yield of transplanted rice. Indian Journal of Agronomy 32:96-97.

Singh, R.S., and S.B. Singh. 1998. Response of rice (Oryza sativa L.) to age of seedlings, and level and time of application of nitrogen under irrigated condition. Indian Journal of Agronomy 43:632635.

Singh, R.S., and S.B. Singh. 1999. Effect of age of seedlings, $\mathrm{N}$-levels and time of application on growth and yield of rice under irrigated condition. Oryza 36:351-354.

Steel, R.G.D., J.H. Torrie, and D.A. Deckey. 1997. Principle and procedures of statistics: A biometrical approach. $3^{\text {rd }}$ ed. p. 400428. McGraw Hill, New York, USA.

Tekrony, D.M., and D.B. Egli. 1991. Relationship of seed vigour to crop yield: A review. Crop Science 31:816-822.

Thanunathan, K., and V. Sivasubramanian. 2002. Age of seedling and crop management practices for high density (HD) grain in rice. Crop Research 24:421-424.

Wagh, R.G., S.A. Khanvilkar, and S.T. Thorat. 1988. Effect of age of seedlings at transplanting, plant densities and nitrogen fertilization on the yield of rice variety R711. Oryza 25:188-190. 